\title{
Investigation of Eighteen Indonesian Mutant Rice Straw Varieties as Ruminant Roughage
}

\section{Teguh Wahyono*,WahidinTeguh Sasongko, Yunida Maharani, Dedi Ansori, Tri Handayani, Dadang Priyoatmojo, Afi Candra Trinugraha}

\author{
Department of Agriculture, Center for Isotope and Radiation Application, National Nuclear Energy Agency of \\ Indonesia (BATAN), National Research and Innovation Agency of Indonesia, Lebak Bulus Raya St. No. 49, Cilandak, \\ South Jakarta, 12440, Indonesia.
}

\begin{abstract}
The comparison was made between eighteen mutant and four non-mutant rice straw variety in Indonesia in terms of chemical composition, nutrient value and in vitro digestibility. The second objective was to determine the correlation between in vitro digestibility parameters and fibrous component in twenty-two Indonesian rice straw varieties. Rice straw samples were collected in triplicate from three replicate plots. The effect of variety on rice straw quality, nutrient values and in vitro digestibility was analyzed using one-way analysis of variance (ANOVA). Results demonstrated that the rice straw varieties differed $(\mathrm{P}<0.05)$ in relation to all nutrient and fiber fractions, except for ether extract content. Neutral detergent fiber (NDF) content was from $66.18 \%$ to $77.22 \%$; acid detergent fiber (ADF) content was from $36.33 \%$ to $49.77 \%$ and hemicellulose content was from $21.67 \%$ to $33.84 \%$. The NDF content of Woyla and Winongo was the lowest of all, 66.18\% and 66.39\%, respectively. Tropiko, as non-mutant variety, had lower ADF content (36.34\%) than Inpari 32 and Ciherang. Woyla, Winongo, Diah Suci and Tropika were only varieties included in the poor class, with the RFV range by 76.94 to 80.33 . The in vitro true digestibility (IVTD) of Winongo and Woyla were the highest $(\mathrm{P}<0.05)$. It was concluded from this study that Woyla and Winongo, as mutant varieties, provided higher nutrient value and digestibility than other varieties. Tropiko, as non-mutant variety, also had relatively great nutrient value. The digestibility of rice straw was negatively associated with NDF and ADF compounds.
\end{abstract}

Keywords | Fiber, In vitro digestibility, Mutant, Rice straw, Variety

Received | April 20, 2021; Accepted | July 08, 2021; Published | September 25, 2021

*Correspondence | Teguh Wahyono, Department of Agriculture, Center for Isotope and Radiation Application, National Nuclear Energy Agency of Indonesia (BATAN), National Research and Innovation Agency of Indonesia, Lebak Bulus Raya St. No. 49, Cilandak, South Jakarta, 12440, Indonesia; Email: teguhwahyono@batan.go.id

Citation | Wahyono T, Sasongko WT, Maharani Y, Ansori D, Handayani T, Priyoatmojo D, Trinugraha AC (2021). Investigation of eighteen Indonesian mutant rice straw varieties as ruminant roughage. Adv. Anim. Vet. Sci. 9(11): 1757-1764.

DOI | http://dx.doi.org/10.17582/journal.aavs/2021/9.11.1757.1764

ISSN (Online) | 2307-8316; ISSN (Print) | 2309-3331

Copyright $(2021$ Wahyono et al. This is an open access article distributed under the Creative Commons Attribution License, which permits unrestricted use, distribution, and reproduction in any medium, provided the original work is properly cited.

\section{INTRODUCTION}

$\mathrm{R}$ ice straw is an important roughage source for livestock in rice-producing countries (Wang et al., 2006). Rice straw also had an important rules as major energy source in the long dry season (Ansah et al., 2017). In Indonesia, although it contains high levels of lignin and silica, rice straw is the primary choice for small-scale farmers due to easily available and quite cheap (Wahyono et al., 2021). Farmers will depend on rice straw as local feed ingredients due to lack of green forage production, especially in the long dry season (Rahman et al., 2010). Over the past 40 years, National Nuclear Energy Agency of Indonesia (BATAN) has developed 33 rice varieties based on mutation breeding. Meanwhile, the selection process is only based on agronomic and grain aspects. It is necessary to had the new paradigm on rice genetic improvement as straw-fodder source for ruminant (Wahyono et al., 2021). Fodder value of rice straw had beneficial effect and significantly contribute to increase the small-scale farmers income (Virk et al., 2019). Furthermore, Virk et al. (2019) stated that the new rice cultivars releasing agents 
should include information about rice straw quality when introducing cultivars in areas where rice straw contributes significantly for ruminant forage.

Nutrient value screening studies of various rice straw have been reported by previous studies (Ansah et al., 2017; Dong et al., 2013; Rahman et al., 2010; Ravi et al., 2019; Subudhi et al., 2020; Virk et al., 2019; Wahyono et al., 2021; Wang et al., 2006). In previous study, Wahyono et al. (2021) highlighted that Ciherang as Indonesian national variety had higher nutrient values in rice straw than four mutant varieties (Atomita 1, Bestari, Inpari Sidenuk and Situ Gintung). However, there are still many Indonesian mutant rice varieties that have not been explored from a ruminant nutrition perspective. Therefore, this research needs to be explored. This study was designed to compare chemical composition, nutrient values and in vitro digestibility between rice straws from mutant and national varieties from Indonesia. The second objective was to determine the correlation between in vitro digestibility parameters and fibrous compounds in twenty-two Indonesian rice straw varieties.

\section{MATERIALS AND METHODS}

\section{RICE CULTIVARS AND STRAW PREPARATION}

The eighteen mutant rice, one non-mutant variety and three national rice varieties (Table 1 ) were grown by the Center for Isotopes and Radiation Application (CIRA), National Nuclear Energy Agency of Indonesia (BATAN), South Jakarta, Indonesia in 2017-2019. Samples were obtained in triplicate from three replicate plots. The whole plant was hand-harvested $10 \mathrm{~cm}$ above the ground and straw was collected by removing the grains. Rice straw samples were placed in paper bags, dried in an oven at $60^{\circ} \mathrm{C}$ for 72 hours and grinded through $1 \mathrm{~mm}$ (mesh 18).

\section{ANALYSIS OF RICE STRAW QUALITY}

Ash, organic matter $(\mathrm{OM})$, ether extract (EE) and crude protein $(\mathrm{CP})$ contents were determined according to the method of the AOAC (2005). Fiber contents, such as neutral detergent fiber (NDF), acid detergent fiber (ADF) and acid detergent lignin (ADL) were determined according to methods by Van Soest et al. (1991). Rice straw nutrient composition analysis was carried out in three repetitions.

Table 1: Characterization of eighteen Indonesian mutant varieties and four non-mutant varieties with regards growth duration plant heights and parentages.

\begin{tabular}{|c|c|c|c|c|c|}
\hline Variety & $\begin{array}{l}\text { Growth duration } \\
\text { (days) }\end{array}$ & $\begin{array}{l}\text { Plant heights } \\
\text { (cm) }\end{array}$ & $\begin{array}{l}\text { Release } \\
\text { year }\end{array}$ & Parentages/Irradiation dose & Reference \\
\hline Atomita 3 & 120 & $105-120$ & 1990 & $627 / 10-3 / \mathrm{Ps} J / 0.2 \mathrm{kGy}$ & CIRA 2020 \\
\hline Atomita 4 & $110-120$ & $110-120$ & 1991 & Cisadane / $0.2 \mathrm{kGy}$ & CIRA 2020 \\
\hline Situgintung & $110-140$ & $105-115$ & 1992 & Seratus Malam / 0.1 kGy & CIRA 2020 \\
\hline Cilosari & $110-120$ & $110-125$ & 1996 & SM-268/Psj mutant x IR-36 & CIRA 2020 \\
\hline Meraoke & $110-120$ & $120-125$ & 2001 & Atomita 4 x IR-64 / $0.2 \mathrm{kGy}$ & CIRA 2020 \\
\hline Woyla & $105-115$ & $115-120$ & 2001 & Atomita 4 x IR-64 / 0.2 kGy & CIRA 2020 \\
\hline Kahayan & $110-115$ & $96-105$ & 2003 & Atomita 4 x IR-64 / 0.2 kGy & CIRA 2020 \\
\hline Winongo & $115-120$ & $110-115$ & 2003 & Atomita 3 x IR-64 / $0.2 \mathrm{kGy}$ & CIRA 2020 \\
\hline Diah Suci & $115-120$ & $110-115$ & 2003 & Cilosari x IR-64 / 0.2 kGy & CIRA 2020 \\
\hline Yuwono & $110-115$ & $95-105$ & 2004 & IR-64 / $0.1 \mathrm{kGy}$ & CIRA 2020 \\
\hline Mayang & $115-120$ & $90-100$ & 2004 & Cilosari x IR-64 / 0.2 kGy & CIRA 2020 \\
\hline Mira 1 & $115-120$ & $105-110$ & 2006 & Cisantana / $0.2 \mathrm{kGy}$ & CIRA 2020 \\
\hline Bestari & $115-120$ & $100-115$ & 2008 & Cisantana / $0.2 \mathrm{kGy}$ & CIRA 2020 \\
\hline Inpari Sidenuk & 103 & 104 & 2011 & Diah Suci / 0.2 kGy & CIRA 2020 \\
\hline Inpari Mugibat & 119 & 104 & 2012 & Cimelati / 0.2 kGy & CIRA 2020 \\
\hline Suluttan Unsrat 1 & 112 & 101 & 2012 & Super Win / 0.2 kGy & CIRA 2020 \\
\hline Suluttan Unsrat 2 & 111 & 99 & 2012 & Super Win / 0.2 kGy & CIRA 2020 \\
\hline Tropiko* & 114 & 106 & 2015 & Koshihikari / IR 36 & CIRA 2020 \\
\hline Mustaban & $120-125$ & $110-115$ & 2018 & Jembar / $0.2 \mathrm{kGy}$ & CIRA 2020 \\
\hline Ciherang* & $116-125$ & $91-106$ & 2000 & $\begin{array}{l}\text { IR18349-53-1-3-1-3/3 x IR19661- } \\
\text { 131-3-1-3//4 x IR } 64\end{array}$ & IAARD 2021 \\
\hline Inpari $30^{*}$ & 111 & 101 & 2012 & Ciherang x IR 64 Sub1 x Ciherang & IAARD 2021 \\
\hline Inpari $32 *$ & 120 & 97 & 2013 & Ciherang x IRBB64 & IAARD 2021 \\
\hline
\end{tabular}

*non-mutant varieties. 
Hemicellulose compound were calculated using following equations:

$$
\text { Hemicellulose (\%) }=N D F(\%)-A D F(\%)
$$

\section{Nutrient VAlue estimation}

Relative feed values (RFV) was determined according to calculation described by Undersander et al. (1993), using following equations:

$$
\text { Dry matter intake (DMI) (\% live weight) }=\frac{120}{\% N D F}
$$

Dry matter digestibility $(D M D)(\%)=88.9-(0.779 \times \% A D F)$

$$
\mathrm{RFV}=\frac{D M D \times D M 1}{1.29}
$$

Based on quality standard by the hay marketing task force of the American forage and grassland council, the RFV were represent forage score: reject $(<75)$, poor $(75-86)$, fair $(87-102)$, good $(103-124)$, premium $(125-151)$ and prime (>151).

\section{IN VITRO DIGESTIBILITY DETERMINATION}

In vitro true digestibility (IVTD) were determined according to in vitro digestibility procedure by Kilic and Gulecyuz (2017) using Daisy II incubator (ANKOM Technology Corp, Fairport, New York). Rumen fluids were collected from three bulls (Approximate average 24-36 months of age and $300 \mathrm{~kg}$ live weight) that were slaughtered at local abattoir in South Tangerang, Banten, Indonesia. Approximately $0.5 \mathrm{~g}$ (DM basis) straw sample were inserted into filter bag and placed inside digestion jar (25 pieces per jar). Rumen liquor $(400 \mathrm{ml})$ were mixed with buffer solution $(1200 \mathrm{ml})$ for each digestion jar and immediately incubated into Daisy ${ }^{\mathrm{II}}$ incubator at $39.5^{\circ} \mathrm{C}$ for $48 \mathrm{~h}$. After completion of incubation, filter bags were rinsed with tap water and dried at $105^{\circ} \mathrm{C}$ for $3 \mathrm{~h}$. All samples were analyzed for NDF with Ankom Fiber Analyzer (ANKOM Technology Corp, Fairport, New York). In vitro assay was carried out in three repetitions. In vitro true digestibility was determined by following equation:

$$
\operatorname{IVTD}(\% \mathrm{DM})=\frac{100-(W 3-(W 1 \times C))}{(W 2 x \% D M)} \times 100
$$

Where IVTD: in vitro true digestibility; W1: filter bag weight; W2: sample weight; W3: final sample weight after NDF analysis; C: the correction of blank filter bag (final oven-dried bag weight/original blank filter bag weight; and DM (dry matter percentage).

\section{STATISTICAL ANALYSIS}

Statistical analysis was performed using SPSS 25.0 (IBM, Armonk, New York, USA). The effect of variety on rice straw quality, nutrient values and in vitro digestibility was analyzed using one-way analysis of variance (ANOVA). Comparison of means between variety were determined using Duncan multiple range test (DMRT). Data of fibrous compounds (NDF and ADF) and IVTD were analyzed by pairwise correlation of variables using SPSS 23.0 (IBM, Armonk, New York, USA).

\section{RESULTS AND DISCUSSION}

\section{Characterization OF EIGHTEEN INDONESIaN} MUTANT VARIETIES AND FOUR NON-MUTANT VARIETIES Atomita 1 is a mutant rice variety that was originally first developed by BATAN, which was obtained in 1982 (data was not presented). In this study, Atomita 3 was the oldest mutant variety, which was discovered in 1990 (Table 1). Meanwhile, the newest mutant variety is Mustaban. The radiation dose of $0.1 \mathrm{kGy}$ and $0.2 \mathrm{kGy}$ are the dose applied in rice plant breeding in Indonesia. Situgintung variety is a highland rice type that has a long groth duration (110-140 days). Most of the mutant varieties in Indonesia are lowland rice type. As presented in Table 1, ten rice cultivars are the results of breeding program from IR 64 variety. Specifically, for Tropiko, this non-mutant variety was obtained from Koshihikari x IR 36 breeding program.

\section{Chemical COMPOSITION AND FIBER FRACTION}

Results on chemical composition and fiber fraction are shown in Table 2. Except EE, different varieties had significant differences on chemical composition and fiber fraction $(\mathrm{p}<0.05)$. Ash content average was from $19.93 \%$ to $35.30 \%$; OM content was from $64.70 \%$ to $80.07 \%$; $\mathrm{CP}$ content was from $3.13 \%$ to $6.78 \%$; EE content was from $2.59 \%$ to $4.24 \%$; NDF content was from $66.18 \%$ to $77.22 \%$; ADF content was from $36.33 \%$ to $49.77 \%$ and hemicellulose content was from $21.67 \%$ to $33.84 \%$.

The ash content of Situgintung and Inpari Sidenuk rice straw was the highest of all (35.30\% and 34.15\%). In contrary, the OM content was highest $(\mathrm{p}<0.05)$ in Ciherang (79.16\%) and Inpari 30 (80.07\%). Woyla and Ciherang had highest CP, 6.78\% and 6.54\%, respectively. The NDF content of Woyla and Winongo was the lowest of all (66.18\% and 66.39\%). Tropiko, as non-mutant variety from BATAN, had lower ADF content (36.34\%) than Inpari 32 and Ciherang. The hemicellulose content of Inpari Mugibat was lower (21.67\%) than all of three Indonesian non-mutant variety (Ciherang, Inpari 30 and Inpari 32).

\section{Nutrient VAlue eSTIMATION}

The nutrient value estimation of twenty two Indonesian rice straw varieties are reported in Table 3. Because the differences of NDF and ADF fractions among all cultivars, significant difference $(\mathrm{P}<0.05)$ was observed for $\mathrm{DMI}$, 
Table 2: Mean chemical composition and fiber fraction of eighteen Indonesian mutant and four non-mutant rice straw varieties from Indonesia

\begin{tabular}{|c|c|c|c|c|c|c|c|}
\hline \multirow[t]{2}{*}{ Variety } & Ash & OM & $\mathrm{CP}$ & $\mathrm{EE}$ & NDF & ADF & Hemicellulose \\
\hline & \multicolumn{7}{|c|}{ \% DM } \\
\hline Atomita 3 & $26.83^{\mathrm{bcd}}$ & $73.17^{\text {ghi }}$ & $5.87^{\mathrm{g}}$ & $2.91^{\mathrm{ab}}$ & $75.15^{\text {cde }}$ & $46.07^{\text {bcde }}$ & $29.08^{\text {cdef }}$ \\
\hline Atomita 4 & $24.90^{\mathrm{b}}$ & $75.10^{\mathrm{h}}$ & $4.96^{\mathrm{f}}$ & $3.66^{\mathrm{ab}}$ & $68.98^{\mathrm{abc}}$ & $40.88^{\mathrm{ab}}$ & $28.10^{\text {cde }}$ \\
\hline Situgintung & $35.30^{\mathrm{j}}$ & $64.70^{\mathrm{a}}$ & $3.96^{\mathrm{cd}}$ & $3.80^{\mathrm{ab}}$ & $74.73^{\text {cde }}$ & $49.77^{\mathrm{e}}$ & $26.17^{\mathrm{abcd}}$ \\
\hline Cilosari & $30.92^{\mathrm{gh}}$ & $69.08^{\mathrm{cd}}$ & $3.71^{\mathrm{bcd}}$ & $3.64^{\mathrm{ab}}$ & $70.22^{\text {abcde }}$ & $43.24^{\text {bcde }}$ & $26.98^{\mathrm{bcd}}$ \\
\hline Meraoke & $28.63^{\text {cdef }}$ & $71.37^{\text {efgh }}$ & $3.85^{\mathrm{cd}}$ & $3.06^{\mathrm{ab}}$ & $74.04^{\text {bcde }}$ & $45.95^{\text {bcde }}$ & $28.09^{\text {cde }}$ \\
\hline Woyla & $28.04^{\text {cde }}$ & $71.96^{\mathrm{fgh}}$ & $6.78^{\mathrm{h}}$ & $3.50^{\mathrm{ab}}$ & $66.18^{a}$ & $41.15^{\mathrm{abc}}$ & $25.03^{\mathrm{abcd}}$ \\
\hline Kahayan & $27.17^{\mathrm{cd}}$ & $72.83^{\mathrm{gh}}$ & $4.43^{e}$ & $3.52^{\mathrm{ab}}$ & $72.36^{\text {abcde }}$ & $44.72^{\text {bcde }}$ & $27.64^{\mathrm{bcd}}$ \\
\hline Winongo & $30.32^{\mathrm{fgh}}$ & $69.68^{\text {cde }}$ & $5.04^{f}$ & $4.24^{\mathrm{b}}$ & $66.39^{a}$ & $41.95^{\mathrm{abcd}}$ & $24.44^{\mathrm{abc}}$ \\
\hline Diah Suci & $26.76^{\mathrm{bcd}}$ & $73.24^{\mathrm{ghi}}$ & $3.67^{\mathrm{bcd}}$ & $3.71^{\mathrm{ab}}$ & $67.27^{\mathrm{ab}}$ & $42.61^{\mathrm{abcd}}$ & $24.66^{\mathrm{abc}}$ \\
\hline Yuwono & $27.08^{\mathrm{cd}}$ & $72.92^{\mathrm{gh}}$ & $5.24^{\mathrm{f}}$ & $3.42^{\mathrm{ab}}$ & $71.26^{\text {abcde }}$ & $42.24^{\mathrm{abcd}}$ & $29.02^{\text {cdef }}$ \\
\hline Mayang & $30.36^{\text {fgh }}$ & $69.64^{\text {cde }}$ & $3.91^{\mathrm{cd}}$ & $2.84^{\mathrm{a}}$ & $70.93^{\text {abcde }}$ & $45.29^{\text {bcde }}$ & $25.65^{\mathrm{abcd}}$ \\
\hline Mira 1 & $26.55^{b c}$ & $73.45^{\mathrm{hi}}$ & $4.96^{f}$ & $3.90^{\mathrm{ab}}$ & $72.69^{\text {abcde }}$ & $42.74^{\mathrm{abcd}}$ & $29.95^{\mathrm{defg}}$ \\
\hline Bestari & $31.62^{\mathrm{hi}}$ & $68.38^{\mathrm{bc}}$ & $3.48^{\mathrm{abc}}$ & $3.66^{\mathrm{ab}}$ & $72.88^{\text {abcde }}$ & $46.51^{\text {bcde }}$ & $26.37^{\mathrm{abcd}}$ \\
\hline Inpari Sidenuk & $34.15^{j}$ & $65.85^{\mathrm{a}}$ & $3.89^{\mathrm{cd}}$ & $3.10^{\mathrm{ab}}$ & $71.44^{\text {abcde }}$ & $48.68^{\mathrm{de}}$ & $22.76^{\mathrm{ab}}$ \\
\hline Inpari Mugibat & $28.87^{\text {defg }}$ & $71.13^{\text {defg }}$ & $4.11^{\mathrm{de}}$ & $2.59^{\mathrm{a}}$ & $69.72^{\mathrm{abcd}}$ & $48.05^{\mathrm{cde}}$ & $21.67^{\mathrm{a}}$ \\
\hline Suluttan Unsrat 1 & $33.45^{\mathrm{ij}}$ & $66.55^{\mathrm{ab}}$ & $3.34^{\mathrm{ab}}$ & $3.34^{\mathrm{ab}}$ & $70.83^{\text {abcde }}$ & $45.74^{\text {bcde }}$ & $25.08^{\mathrm{abcd}}$ \\
\hline Suluttan Unsrat 2 & $30.85^{\mathrm{gh}}$ & $69.15^{\mathrm{cd}}$ & $3.54^{\mathrm{abc}}$ & $3.53^{\mathrm{ab}}$ & $76.20^{\text {de }}$ & $48.54^{\mathrm{de}}$ & $27.66^{\mathrm{bcd}}$ \\
\hline Tropiko* & $29.66^{\text {efgh }}$ & $70.34^{\text {cdef }}$ & $3.23^{\mathrm{ab}}$ & $3.07^{\mathrm{ab}}$ & $70.17^{\text {abcde }}$ & $36.34^{\mathrm{a}}$ & $33.84^{\mathrm{g}}$ \\
\hline Mustaban & $27.79^{\text {cde }}$ & $72.21^{\mathrm{fgh}}$ & $3.13^{\mathrm{a}}$ & $3.14^{\mathrm{ab}}$ & $70.30^{\text {abcde }}$ & $45.93^{\text {bcde }}$ & $24.37^{\mathrm{abc}}$ \\
\hline Ciherang* & $20.84^{\mathrm{a}}$ & $79.16^{\mathrm{i}}$ & $6.54^{\mathrm{h}}$ & $2.96^{\mathrm{ab}}$ & $72.46^{\text {abcde }}$ & $45.70^{\text {bcde }}$ & $26.75^{\mathrm{bcd}}$ \\
\hline Inpari $30^{*}$ & $19.93^{\mathrm{a}}$ & $80.07^{\mathrm{i}}$ & $5.26^{\mathrm{f}}$ & $3.87^{\mathrm{ab}}$ & $74.62^{\text {cde }}$ & $41.41^{\mathrm{abc}}$ & $33.20^{\mathrm{fg}}$ \\
\hline Inpari $32^{*}$ & $28.25^{\mathrm{cdef}}$ & $71.75^{\text {efgh }}$ & $3.46^{\mathrm{abc}}$ & $3.82^{\mathrm{ab}}$ & $77.22^{\mathrm{e}}$ & $44.66^{\text {bcde }}$ & $32.56^{\mathrm{efg}}$ \\
\hline SEM & 0.467 & 0.467 & 0.159 & 0.087 & 0.509 & 0.522 & 0.468 \\
\hline
\end{tabular}

OM (organic matter), CP (crude protein), EE (ether extract), NDF (neutral detergent fiber), ADF (acid detergent fiber), SEM (standard error of mean). Values in a column followed by a similar superscripts are statistically similar after the DMRT test at a level of confidence $95 \%$.

DMD and RFV parameters. The DMI value in the range of 1.55 and $1.82 \%$ of animal weight with the highest $(\mathrm{P}<0.05)$ reported in Woyla variety. Woyla, Winongo and Diah Suci also had higher DMI value than Inpari 30 and Inpari $32(\mathrm{P}<0.05)$. Tropiko variety had highest $\mathrm{DMD}$ estimation $(60.59 \% ; \mathrm{P}<0.05)$, higher than non-mutant variety (Inpari 32 and Ciherang). The range of RFV was from 62.74 to 80.33 with seventeen varieties included in the reject class. Atomita 4, Woyla, Winongo, Diah Suci and Tropiko were only varieties included in the poor class, with the RFV range by 76.94 to 80.33 .

IN VITRO TRUE DIGESTIBILITY AND RELATIONSHIP BETWEEN CHEMICAL COMPOSITION AND DIGESTIBILITY OF RICE STRAW

The IVTD of twenty two rice straw varieties is presented in Figure 1. Among all varieties, the IVTD of Winongo and Woyla were the highest $(\mathrm{P}<0.05), 56.48 \%$ and $56.37 \%$, respectively, but there were no significant differences with Tropiko and Diah Suci. In contrary, Inpari 30 and Inpari 32 had lowest IVTD value, $43.01 \%$ and $42.26 \%$, respectively. As reported in Table 4, NDF content had significantly and strong negatively associated with IVTD $(r=-0.793$; $\mathrm{P}<0.01)$. The correlation between IVTD and ADF content also strong enough and significant $(\mathrm{r}=-0.430 ; \mathrm{P}<0.05)$. The correlation between rice straw IVTD and ash, EE, CP, and hemicellulose were statistically non-significant.

\section{DifFERENT VARIETIES INFLUENCE THE CHEMICAL} COMPOSITION AND FIBER FRACTION

The aim of this study was to evaluate nutrient composition and fiber fraction for mutant and non-mutant rice straw varieties in Indonesia, as well as determining differences among varieties. Previous study demonstrated that the differences in chemical composition between varieties may be related to genetic expression characteristics, due to all varieties are grown under the similar environment conditions (Wahyono et al., 2021). Significant differences in forage quality relate to varietal variations in cell wall compounds (Huang et al., 2020). The similar findings 
also resulted by Rahman et al. (2010); Ravi et al. (2019); Subudhi et al. (2020); Virk et al. (2019) and Wahyono et al. (2021). Others also reported similar results in oat straw (Kafilzadeh and Heidary, 2013; Kafilzadeh et al., 2012); wheat straw (Joshi et al., 2019); maize stover (HomannKee et al., 2013; Zaidi et al., 2013); common vetch (Huang et al., 2020); field pea (Wamatu et al., 2017) and brassica (Keim et al., 2020).

Table 3: Nutrient value estimation of eighteen Indonesian mutant and four non-mutant rice straw varieties from Indonesia.

\begin{tabular}{|c|c|c|c|}
\hline \multirow[t]{2}{*}{ Variety } & DMI & DMD & RFV \\
\hline & \% weight & $\%$ & \\
\hline Atomita 3 & $1.60^{\mathrm{ab}}$ & $53.01^{\text {abcd }}$ & 65.68 \\
\hline Atomita 4 & $1.74^{\text {bcde }}$ & $57.05^{\mathrm{de}}$ & 76.94 \\
\hline Situgintung & $1.61^{\mathrm{ab}}$ & $50.13^{a}$ & 63.03 \\
\hline Cilosari & $1.71^{\text {abcde }}$ & $55.22^{\mathrm{abcd}}$ & 73.44 \\
\hline Meraoke & $1.62^{\mathrm{abc}}$ & $53.10^{\text {abcd }}$ & 66.74 \\
\hline Woyla & $1.82^{\mathrm{e}}$ & $56.84^{\text {cde }}$ & 80.20 \\
\hline Kahayan & $1.66^{\text {abcde }}$ & $54.06^{\text {abcd }}$ & 69.78 \\
\hline Winongo & $1.81^{\mathrm{de}}$ & $56.22^{\text {bcde }}$ & 79.12 \\
\hline Diah Suci & $1.79^{\text {cde }}$ & $55.71^{\text {bcde }}$ & 77.07 \\
\hline Yuwono & $1.68^{\text {abcde }}$ & $56.00^{\text {bcde }}$ & 73.15 \\
\hline Mayang & $1.69^{\text {abcde }}$ & $53.62^{\text {abcd }}$ & 70.54 \\
\hline Mira 1 & $1.65^{\mathrm{abcd}}$ & $55.61^{\text {bcde }}$ & 71.20 \\
\hline Bestari & $1.65^{\text {abcd }}$ & 52.67 abcd & 67.54 \\
\hline Inpari Sidenuk & $1.69^{\text {abcde }}$ & $50.98^{\mathrm{ab}}$ & 67.21 \\
\hline Inpari Mugibat & $1.72^{\text {bcde }}$ & $51.47^{\mathrm{abc}}$ & 68.75 \\
\hline Suluttan Unsrat 1 & $1.69^{\text {abcde }}$ & $53.27^{\text {abcd }}$ & 69.96 \\
\hline Suluttan Unsrat 2 & $1.58^{\mathrm{ab}}$ & $51.08^{\mathrm{ab}}$ & 62.74 \\
\hline Tropiko* & $1.71^{\text {abcde }}$ & $60.59^{e}$ & 80.33 \\
\hline Mustaban & $1.71^{\text {abcde }}$ & $53.12^{\text {abcd }}$ & 70.33 \\
\hline Ciherang* & $1.66^{\text {abcde }}$ & $53.30^{\text {abcd }}$ & 68.64 \\
\hline Inpari $30^{*}$ & $1.61^{\mathrm{ab}}$ & $56.64^{\text {bcde }}$ & 70.64 \\
\hline Inpari $32^{*}$ & $1.56^{\mathrm{a}}$ & $54.11^{\text {abcd }}$ & 65.34 \\
\hline SEM & 0.012 & 0.407 & 0.907 \\
\hline
\end{tabular}

DMI (dry matter intake), DMD (dry matter digestibility), RFV (relative feed value), SEM (standard error of mean), Values in a column followed by a similar superscripts are statistically similar after the DMRT test at a level of confidence $95 \%$.

After fiber and silica, $\mathrm{CP}$ content represent the nutrient quality of rice straw (Wahyono et al., 2021). For mutant varieties, $\mathrm{CP}$ concentrations varies from $3.13 \%$ to $6.78 \%$, while $\mathrm{CP}$ concentrations for non-mutant varieties are from $3.23 \%$ to $6.54 \%$. Our results were similar to previous study by Wahyono et al. (2021) and Rahman et al. (2010). This differences might be influenced by leaf: Stem ratio in rice straw. As fiber sources, the important quality characteristics are the composition of NDF and $\mathrm{ADF}$. The mean of NDF content of mutant varieties are ranging from $66.18 \%$ to $75.15 \%$, while the ADF contents are from $40.88 \%$ to $48.68 \%$. Most of the mutant varieties had lower NDF concentrations than Ciherang as national variety. Ciherang had high NDF and $\mathrm{ADF}$ concentration by $72.46 \%$ and $45.70 \%$ respectively, while Inpari 30 and Inpari 32 contains highest hemicellulose content $(33.20 \%$ and $32.56 \%$, respectively). Previous studies reported that the mean of NDF contents of rice straw in Indonesia varied from $69.84 \%$ to $73.35 \%$ (Wahyono et al., 2021) and 68.67\% (Firsoni et al., 2019). The NDF and ADF contents of rice straw grown in Malaysia, with a similar climate location, are $80.80 \%$ and $58.90 \%$, respectively (Nazli et al., 2018). Several studies also demonstrated that $\mathrm{ADF}$ value of rice straw was in the range of $25.30 \%$ to $38.80 \%$ (Wang et al., 2006); $41.38 \%$ to $46.32 \%$ (Rahman et al., 2010 ); $43.40 \%$ to $48.36 \%$ (Ansah et al., 2017) and $47.40 \%$ to $57.70 \%$ (Virk et al., 2019). The differences in nutrient composition between studies may be caused by the differences in stem: Leaf ratio, climate conditions during cultivation, soil management, crop maturity during harvesting and post-harvest handling management (Huang et al., 2020; Wahyono et al., 2021). Based on the overall fiber parameters, Woyla and Winongo had the lowest fiber content. Gene mutant in crop rice had beneficial effect on the nutrient value of rice straw (Wang et al., 2006). However, further investigations are needed to develop this beneficial gene.

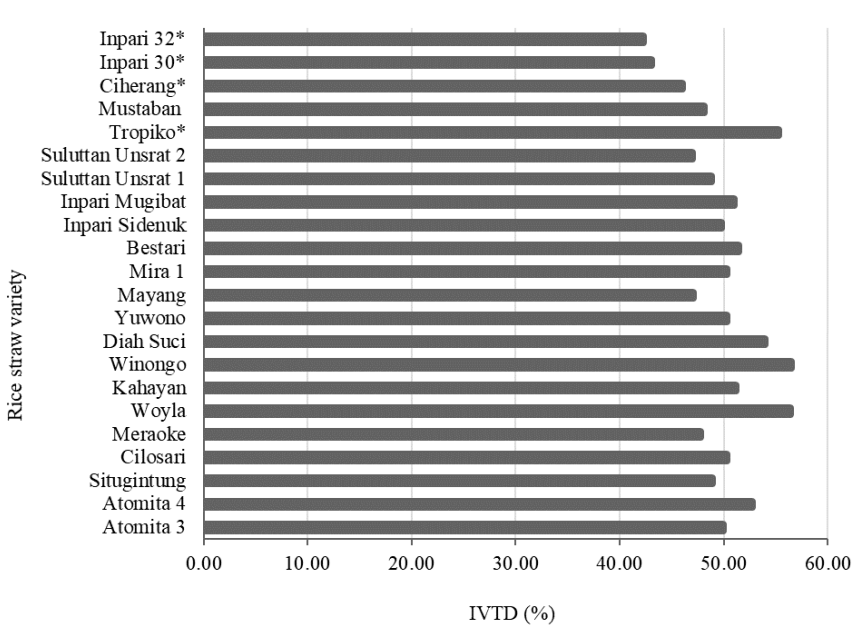

Figure 1: Mean in vitro true digestibility of eighteen Indonesian mutant and four non-mutant rice straw varieties from Indonesia. IVTD (in vitro true digestibility).

It is interesting to note that, Tropiko, as non-mutant variety had low NDF and ADF contents (Table 2). This variety obtained from Koshihikari x IR 36 breeding program (Table 1). Less information is available in the literature of utilization of Koshihikari variety as livestock feed, but we assume that Koshihikari had beneficial gene to develop the new dual purpose rice variety. However, this assumption needs to be investigated further. Leaf Star variety, as 
recently improved rice cultivar from Koshihikari variety, produces a large straw biomass and had a large amount of non structural carbohydrate in straw (Ookawa et al., 2010). Previous study reported that Koshihikari leaves produce low oxalate content, so that the usage for livestock forage can be increased (Miyagi et al., 2019).

\section{DIFFERENCES IN QUALITY VALUE PREDICTIONS}

Based on the practically in the field, it is necessary to predict the quality value based on the calculation of fiber fraction (Undersander et al., 1993; Wahyono et al., 2021). Relative feed value is commonly used in forage indexing to help ranking of potential energy intake of feed stuffs (Fekadu et al., 2017). Lower NDF and ADF value related to higher DMI, DMD and RFV estimations. Lower NDF value may result in low physical fill in the rumen over time, thus allows higher voluntary feed intake (Kafilzadeh et al., 2012). A low ADF content related to high digestibility on feed (Kilic and Gulecyuz, 2017). Dry matter intake, DMD and RFV associated with feed corvertion ratio (FCR) and daily gain on cattle (Nazli et al., 2018). In terms of RFV, the differences in rice straw variety have an impact on their biological values.

Except Atomita 4, Woyla, Winongo, Diah Suci and Tropiko, all rice straw varieties included in reject class forage. Similar to our results, Wahyono et al. (2021) reported that the range in $\mathrm{RFV}$ of five rice straws in Indonesia varied by 60.99-68.89. However, our study showed that four mutant rice varieties (Atomita 4, Woyla, Winongo and Diah Suci) had higher RFV than other studies (Fekadu et al., 2017; Firsoni et al., 2019; Wahyono et al., 2021). The differences in RFV between studies may be caused by the differences in crop maturity during harvesting and post-harvest handling management. Rice straw contain lower RFV than other forage. The RFV of sorghum, tropical native grass, Brachiaria decumbens and legume are from 112.44 to 144.65 (Wahyono et al., 2019a); 70.36 to 89.41 (Wahyono et al., 2019b); 74.83 to 84.17 (Suhaimi et al., 2017) and 123.71 to 161.03 (Sasongko et al., 2019), respectively. Jahansouz et al. (2014) reported that the RFV estimation of corn and sorghum are from 118.70 to 124.30 and 98.40 to 110.00 , respectively. The nutrient value prediction by Undersander et al. (1993) is obtained from the Alfalfa standard value (Wahyono et al., 2021), thus rice straw will be included in the low-quality forage group. Although rice straw had low nutrient quality, it is particularly useful when high quality of forage are expensive and limited (Nazli et al., 2018).

\section{DIFFERENCES IN IN VITRO TRUE DIGESTIBILITY AND ITS RELATIONSHIP WITH CHEMICAL COMPOSITION AND FIBER FRACTION}

It appears from IVTD content that Woyla and Winongo were superior to all national control varieties (Ciherang,
Inpari 30 and Inpari 32). The IVTD values ranged between $46.98 \%$ and $56.48 \%$ in the mutant varieties and from $42.26 \%$ to $55.24 \%$ in the non-mutant varieties (Figure 1). In our study, rice straw containing high levels of NDF and ADF (Table 2) tended to produce low IVTD. The IVTD value had negative association with NDF and ADF compounds (Table 4). Similar results reported by Zaidi et al. (2013); Wamatu et al. (2017) and Ravi et al. (2019). Neutral detergent fiber content, particularly lignocellulose compounds had negative effect on ruminal degradation and total tract digestibility (Jayanegara et al., 2019). The NDF, $\mathrm{ADF}$ and silica are the negative traits that could reduce the digestibility of rice straw (Ravi et al., 2019). Conversely, the relatively higher in digestibility could be an indication that plant cell wall degradation was not impeded in some rice straw varieties, possibly due to less silica and lignin content (Ansah et al., 2017).

Table 4: Correlation between nutrient compounds of rice straws from 22 varieties and their IVTD.

ash EE PK NDF ADF $\begin{aligned} & \text { Hemicel- } \\ & \text { lulose }\end{aligned}$
$\operatorname{IVTD}(\%) 0.233^{\text {ns }} 0.114^{\text {ns }} 0.149^{\text {ns }}-0.793^{* *}-0.43^{*}-323^{\text {ns }}$
${ }^{n \text { ns }}$ non significant; ${ }^{*} \mathrm{P}<0.05 ;{ }^{* *} \mathrm{P}<0.01 ;$ IVTD (in vitro true
digestibility), EE (ether extract), NDF (neutral detergent fiber),
ADF (acid detergent fiber).

Apparently, the proportion of leaf-stem ratio in each rice variety also affect the value of IVTD, however this needs further analysis. The nutritive values of straws are dependent upon the proportion and quality of the stem (Wang et al., 2006). Differences in the digestibility of feedstuffs from different varieties not only due to chemical composition, but also to different stem, leaves and grain ratios (Kafilzadeh and Heidary, 2013). Based on the perspective of resistance to crop disease, low digestibility and high lignin content are also related to the characteristics of plants that are diseases resistant. High disease resistant varieties of crops may tend to have lower nutritive quality of straw (Wamatu et al., 2017). In our study, this phenomenon was demonstrated by Suluttan Unsrat 1 and Suluttan Unsrat 2 rice straw varieties.

Our results for IVTD value were similar to that reported by Firsoni et al. (2020) but lower than reported by Wahyono et al. (2020). The IVTD value in this study also lower than IVTD from tropical native grass and legume as reported by Wahyono et al. (2019b) and Sasongko et al. (2019). Rice straws are characterized by their higher ratio of structural carbohydrate (i.e. hemicellulose and cellulose) to readily fermentable carbohydrates, thus they have low energy availability for ruminal fermentation. The most limiting factor to the nutrient quality of rice straw is silica, and then lignin (Van Soest, 2006). 


\section{CONCLUSIONS AND} RECOMMENDATION

As mutant varieties, Woyla and Winongo had low fiber content which is represented by low NDF and ADF values. The nutrient value and digestibility of Woyla and Winongo also significantly higher than other varieties. Tropiko, as non-mutant variety, also had relatively high nutrient value. It is revealed from this study that the digestibility of rice straw was negatively associated with NDF and ADF compounds. Utilization of rice straw as forage should be combined with other high nutrient value feed ingredients because of its relatively low nutrient value (reject-poor class). The results of this study can be used as a starting point for rice plant breeding in Indonesia, to produce high nutritious rice plant from a forage perspective.

\section{ACKNOWLEDGEMENTS}

The authors acknowledge financial support from Center for Isotope and Radiation Application (CIRA), National Nuclear Energy Agency of Indonesia (BATAN). This research was provided by the National Research and Innovation Agency of Indonesia (BRIN) through "Program Pendukung Beasiswa Saintek". The authors would like to thank Dr. Sobrizal, Mrs. Ita Dwimahyani and Plant Breeding Laboratory Staff for their assistance in the rice field management.

\section{NOVELTY STATEMENT}

There are many Indonesian mutant rice varieties that have not been explored from a ruminant nutrition perspective. Our novelty resides in the point of view of investigating various rice straw varieties in Indonesia, especially mutant vs non-mutant. We found that Woyla and Winongo (mutant varieties) and Tropiko (non-mutant variety) had a good prospects for use as roughages

\section{AUTHOR'S CONTRIBUTION}

Teguh Wahyono designed the experiment, performed in vitro gas analysis, collected the data and wrote the firstdraft article. Wahidin Teguh Sasongko supervised the experiment, conducted in vitro analysis and revised the manuscript. Yunida Maharani performed the chemical composition and in vitro gas analysis. Dedi Ansori prepared raw sample and performed the chemical composition analysis. Tri Handayani performed in vitro analysis and collected the data. Dadang Priyoatmojo supervised the experiment and prepared in vitro analysis. Afi Candra Trinugraha analyze the data and revised the manuscript.
CONFLICT OF INTEREST

The authors have declared no conflict of interest.

\section{REFERENCES}

-Ansah T, Dogbe W, Cudjoe S, A-R, Iddrisu AB, Eseoghene AS (2017). Agronomic performance of five rice varieties and nutritive value of the straw from these varieties. West Afr. J. Appl. Ecol., 25(1): 1-10.

-AOAC (2005). Official Method of Analysis. Maryland: Association of Official Analytical Chemists.

- CIRA (2020). Center for Isotope and Radiation Application (2020). Pemuliaan tanaman dengan teknik mutasi radiasi. Jakarta: Badan Tenaga Nuklir Nasional.

- Dong CF, Shen YX, Ding CL, Xu NX, Cheng YH, Gu HR (2013). The feeding quality of rice (Oryza sativa L.) straw at different cutting heights and the related stem morphological traits. Field Crops Res., 141: 1-8. https://doi.org/10.1016/j. fcr.2012.11.003

- Fekadu D, Walelegn M, Terefe G (2017). Indexing Ethiopian feed stuffs using relative feed value: Dry forages and roughages, energy supplements, and protein supplements. J. Biol. Agric. Healthc., 7(21): 57-60.

-Firsoni, Ekani N, Wahyono T (2020). Effect of different level of urea addition for rice straw fermentation ppplication: In vitro evaluation. International conference: Improving tropical animal production for food security, Kendari. IOP Conf. Ser. Earth Environ. Sci., pp. 465. https://doi. org/10.1088/1755-1315/465/1/012016

- Firsoni, Hardani SNW, Wahyono T (2019). Fiber content and relative feed value estimation of gamma irradiated rice straw. In proceedings of $9^{\text {th }}$ annual basic science international conference, Malang. IOP Conf. Ser. Mater. Sci. Eng., pp. 546. https://doi.org/10.1088/1757-899X/546/4/042008

-Homann-Kee Tui S, Blümmel M, Valbuena D, Chirima A, Masikati P, van Rooyen AF, Kassie GT (2013). Assessing the potential of dual-purpose maize in Southern Africa: A multi-level approach. Field Crops Res. 153: 37-51. https:// doi.org/10.1016/j.fcr.2013.07.002

-Huang Y, Matthew C, Li F, Nan Z (2020). Comparative effects of stovers of four varieties of common vetch on growth performance, ruminal fermentation, and nutrient digestibility of growing lambs. Animals, 10: 1-12. https:// doi.org/10.3390/ani10040596

-IAARD (2021). Indonesian Agency for Agricultural Research and Development (2021). https://www.litbang.pertanian. go.id/varietas. Accessed March, $20^{\text {th }} 2021$.

-Jahansouz MZ, Afshar RK, Heidari H, Hashemi M (2014). Evaluation of yield and quality of sorghum and millet as alternative forage crops to corn under normal and deficit irrigation regimes. Jordan J. Agric. Sci., 10(4): 699-715. https://doi.org/10.12816/0031747

- Jayanegara A, Ridla M, Nahrowi, Laconi EB (2019). Estimation and validation of total digestible nutrient values of forage and concentrate feedstuffs. Proc. $9^{\text {th }}$ Ann. Basic Sci. Int. Conf. Malang IOP Conf. Ser. Mater. Sci. Eng., 546: 1-5. https://doi.org/10.1088/1757-899X/546/4/042016

- Joshi AK, Kumar U, Mishra VK, Chand R, Chatrath R, Naik R, Biradar S, Singh RP, Budhlakoti N, Devulapalli R, Blümmel $M$ (2019). Variations in straw fodder quality and grainstraw relationships in a mapping population of 287 diverse spring wheat lines. Field Crops Res., pp. 243. https://doi. 
org/10.1016/j.fcr.2019.107627

- Kafilzadeh F, Heidary N (2013). Chemical composition, in vitro digestibility and kinetics of fermentation of whole-crop forage from 18 different varieties of oat (Avena sativa L.). J. Appl. Anim. Res., 41(1): 61-68. https://doi.org/10.1080/ 09712119.2012.739084

- Kafilzadeh F, Heidary N, Bahraminejad S (2012). Variety effect on composition, kinetics of fermentation and in vitro digestibility of oat (Avena sativa L.) straw and its neutral detergent fibre. S. Afr. J. Anim. Sci. 42(4): 406-415. https:// doi.org/10.4314/sajas.v42i4.9

-Keim JP, Gandarillas M, Benavides D, Cabanilla J, Pulido RG, Balocchi OA, Bertrand A (2020). Nutrient concentrations and profile of non-structural carbohydrates vary among different brassica forages. Anim. Prod. Sci., 60: 1503-1513. https://doi.org/10.1071/AN19472

- Kilic U, Gulecyuz E (2017). Effects of some additives on in vitro true digestibility of wheat and soybean straw pellets. Open Life Sci., 12: 206-213. https://doi.org/10.1515/biol-20170024

-Miyagi A, Noguchi K, Tokida T, Usui Y, Nakamura H, Sakai H, Hasegawa T, Kawai-Yamada M (2019). Oxalate contents in leaves of two rice cultivars grown at a free-air $\mathrm{CO}_{2}$ enrichment (FACE) site. Plant Prod. Sci., 22(3): 407-411. https://doi.org/10.1080/1343943X.2019.1598272

- Nazli MH, Halim RA, Abdullah AM, Samsudin AA (2018). Potential of feeding beef cattle with whole corn crop silage and rice straw in Malaysia. Trop Anim. Health Prod., 50: 1119-1124. https://doi.org/10.1007/s11250-018-1538-2

- Ookawa T, Yasuda K, Kato H, Sakai M, Seto M, Sunaga K, Motobayashi T, Tojo S, Hirasawa T (2010). Biomass production and lodging resistance in 'leaf star', a new longculm rice forage cultivar. Plant Prod. Sci., 13(1): 58-66. https://doi.org/10.1626/pps.13.58

- Rahman MM, Alam MR, Amin MR, Das NG (2010). Comparative study of the nutritive values of the different varieties of rice straw. Bangladesh J. Anim. Sci., 39(1 and 2): 75-82. https://doi.org/10.3329/bjas.v39i1-2.9679

- Ravi D, Subba Rao IV, Jyothi B, Sharada P, Venkateswarlu G, Reddy Ch RK, Prasad KVSV, Blümmel M (2019). Investigation of fifteen popular and widely grown Indian rice varieties for variations in straw fodder traits and grainstraw relationships. Field Crops Res., pp. 241. https://doi. org/10.1016/j.fcr.2019.107566

- Sasongko WT, Zuhri MH, Yunita E, Maharani Y, Wahyono T (2019). Nutrients composition, relative feed value and in vitro digestibility of some tropical legume species in Indonesia. $8^{\text {th }}$ Int. Semin. Trop. Anim. Prod. Yogyakarta, pp. 86-89.

- Subudhi HN, Prasad KVSV, Ramakrishna Ch, Rameswar PS, Pathak H, Ravi D, Khan AA, Padmakumar V, Blümmel M (2020). Genetic variation for grain yield, straw yield and straw quality traits in 132 diverse rice varieties released for different ecologies such as upland, lowland, irrigated and salinity prone areas in India. Field Crops Res., 245: 107626. https://doi.org/10.1016/j.fcr.2019.107626
- Suhaimi D, Sharif S, Normah MA, Norain NM, Wan Syahidah $H$ (2017). Estimating relative feed value of local Brachiaria decumbens. Malaysia J. Vet. Res., 8(2): 78-82.

-Undersander D, Mertens DR, Thiex N (1993). Forage analyses procedures. Method A1: Relative Feed Value Index. Omaha: National Forage Testing Association.

- Van Soest PJ (2006). Rice straw, the role of silica and treatments to improve quality. Anim. Feed Sci. Technol., 130(3-4): 137-171. https://doi.org/10.1016/j.anifeedsci.2006.01.023

- Van Soest PJ, Robertson JB, Lewis BA (1991). Methods for dietary fiber, neutral detergent fiber, and nonstarch polysaccharides in relation to animal nutrition. J. Dairy Sci., 74: 3583-3597. https://doi.org/10.3168/jds.S00220302(91)78551-2

-Virk P, Xianglin L, Blümmel M (2019). A note on variation in grain and straw fodder quality traits in 437 cultivars of rice from the varietal groups of aromatic, hybrids, indica, new planting types and released varieties in the Philippines. Field Crops Res., 233: 96-100. https://doi.org/10.1016/j. fcr.2018.12.007

-Wahyono T, Ansori D, Hardani SHW, Maharani Y, Kurniawan $\mathrm{W}$ (2020). The effects of fermentation using gammairradiated Aspergillus niger and adding rice bran on rice straw digestibility: In vitro study. Int. Conf. Improv. Trop. Anim. Prod. Food Security, Kendari IOP Conf. Ser. Earth Environ. Sci., pp. 465. https://doi.org/10.1088/17551315/465/1/012017

-Wahyono T, Jatmiko E, Firsoni, Hardani SHW, Yunita E (2019b). Evaluasi nutrien dan kecernaan in vitro beberapa spesies rumput lapangan tropis di Indonesia. Sains Peternakan. 17(2): 17-23. https://doi.org/10.20961/sainspet. v17i2.29776

-Wahyono T, Sasongko WT, Sugoro I, Firsoni (2021). Nutrient value and digestibility variation of five rice straw cultivars in Indonesia as ruminant roughage. Adv. Anim. Vet. Sci., 9(1): 73-81. https://doi.org/10.17582/journal. aavs/2021/9.1.73.81

-Wahyono T, Sugoro I, Jayanegara A, Wiryawan KG, Astuti DA (2019a). Nutrient profile and in vitro degradability of new promising mutant lines sorghum as forage in Indonesia. Adv. Anim. Vet. Sci., 7(9): 810-818. https://doi.org/10.17582/ journal.aavs/2019/7.9.810.818

-Wamatu J, Alkhatib A, Abate D, Kemal SA, Rischkowsky B (2017). Nutritive value of field pea (Pisum Sativum L.) straw as influenced by variety, season, botanical fractions and urea pretreatment. Anim. Feed Sci. Tech., 225: 54-61. https:// doi.org/10.1016/j.anifeedsci.2017.01.003

-Wang H, Wu Y, Liu J, Qian Q (2006). Morphological fractions, chemical compositions and in vitro gas production of rice straw from wild and brittle culm 1 variety harvested at different growth stages. Anim. Feed Sci. Tech., 129: 159171. https://doi.org/10.1016/j.anifeedsci.2005.12.009

-Zaidi PH, Vinayan MT, Blümmel M (2013). Genetic variability of tropical maize stover quality and the potential for genetic improvement of food-feed value in India. Field Crops Res., 153: 94-101. https://doi.org/10.1016/j.fcr.2012.11.020 